\title{
Inside Insite
}

\author{
The cost-effectiveness of supervised injection facilities \\ Cory Lefebvre, Lauren Crosby, Adam Kovacs-Litman \\ Faculty Reviewer: Ava John-Baptiste, PhD (Department of Epidemiology \& Biostatistics)
}

\section{ABSTRACT}

The debate around supervised injection facilities (SIF) rages on more than a decade after the opening of Insite, Canada's first supervised injection site in Vancouver. Recently, an article published in the journal Addiction reignited the discussion when it made a financial case for introducing facilities in Ottawa and Toronto. The model predicts that the introduction of two SIFs in Ottawa and three in Toronto would be a cost-savings measure to prevent the spread of human immunodeficiency virus (HIV) and hepatitis C virus (HCV) among intravenous drug users (IVDUs). Over 600 total cases of HIV or HCV are projected to be averted in a 20 -year period, saving over $\$ 40$ million in healthcare costs in Toronto and over $\$ 30$ million in Ottawa. Opponents deny the benefits of safe injection sites despite research conducted on Insite, which suggest that these facilities have tremendous utility and are economically viable. Insite targets and attracts high-risk IVDUs, fosters safer injection habits and prevents transmission of needle-sharing diseases. Insite's facilities also offer complementary detoxification and rehabilitation services and encourage users to register for these programs. In contrast to arguments made by opponents, Insite has not been found to increase incidental overdoses, neighbourhood crime rates, or public disposal of needles. Given the outcomes of research conducted on Insite, the viability of similar facilities in Ontario should be further explored.

\section{INTRODUCTION}

Insite, the first supervised injection facility (SIF) in Canada, has been operating in the Downtown Eastside neighbourhood of Vancouver since 2003 with well-documented evidence supporting its benefit in infection control among intravenous drug users (IVDUs). ${ }^{1}$ At the facility, drug users are able to inject drugs using clean equipment under the supervision of specially trained nurses in order to prevent transmission of diseases like human immunodeficiency virus (HIV) and hepatitis C virus (HCV) through the sharing of used needles. Even though Insite receives strong local and national support from Canadians, ${ }^{2}$ there remains a vocal opposition among government officials and members of the public. ${ }^{3-5}$ Reports citing the potential benefits of introducing similar sites in Ottawa and Toronto ${ }^{6}$ have been met with resistance. ${ }^{3-5}$

\section{FINANCIAL CASE}

A recent paper on the subject explored the financial feasibility of having between zero and five facilities in Ottawa and Toronto in the context of reducing HIV and HCV transmission among IV-
DUs. ${ }^{6}$ The incremental cost effective ratio (ICER) for one facility in Toronto was \$10 763/QALY (Quality Adjusted Life Year) and the ICER for one facility in Ottawa was \$6127/QALY. Over a 20-year period, it was projected that one SIF would avert $164 \mathrm{HIV}$ and 454 HCV infections and $358 \mathrm{HIV}$ and $323 \mathrm{HCV}$ infections in Toronto and Ottawa respectively. In the same time period, one facility in Toronto would incur $\$ 33.1$ million in undiscounted direct operating costs but save $\$ 42.7$ million in healthcare costs from averted infections. In Ottawa, one facility would incur $\$ 31.5$ million in operating costs and save \$32.2 million in healthcare costs. Additional facilities would provide decreasing incremental benefit but greater absolute reduction in HIV and HCV transmission. Using a willingness to pay threshold of $\$ 50000 / \mathrm{QALY}$, the authors recommended that establishing two facilities in Ottawa and three in Toronto would be cost-effective. The authors only considered benefits accrued from a reduction in HIV and HCV transmission when exploring cost effectiveness. Other potential benefits like reductions in Hepatitis B virus transmission, unintentional overdosing, crime rates, and injection related-litter were not reflected in their conclusions. Even with an underestimation of potential benefits, the paper presents a strong economic rationale for the introduction of SIFs in Toronto and Ottawa.

Conclusions presented in the paper are consistent with previous research conducted on Insite. Insite has been shown to be cost-effective for reducing HIV transmission and mortality with decreased needle sharing and education of safe practices having a significant impact. ${ }^{78}$ The decrease in needle sharing has led to an estimated \$14 million in healthcare savings and a gain of 920 lifeyears over a 10-year period. ${ }^{8}$ Despite strong economic evidence for establishing SIFs, opponents argue that SIFs do not function as prescribed, that they increase the risk of crime in the area, and that rehabilitation programs are a better target for financial support. ${ }^{5}$

\section{POLITICAL SUPPORT}

Support for SIFs is lacking in both federal and municipal governments. The previous federal government under Conservative leadership was staunchly opposed to SIFs and attempted to repeal the CSDA (Controlled Substances and Drugs Act) exemption under which Insite was allowed to operate. ${ }^{9,10}$ Insite challenged the government's actions and the case was eventually brought before the Supreme Court of Canada which sided against the federal government and forced the Minister of Health to extend the exemption. ${ }^{11}$ Before the end of the 2015 session, Parliament passed Bill C-2 which granted the Minister of Health the power to authorize exemptions for SIFs but also increased the barriers to obtaining an exemption. The purpose of Bill C-2, according to Ms Cathy McLeod, MP, Par- 
liamentary Secretary to the Minister of Health and Western Economic Diversification at the time, was to establish an appropriate and transparent community consultation and application process with clear guidelines and criteria. ${ }^{12}$ Among the many added requirements, applicants for exemptions now require letters of opinion from key stakeholders, such as the municipal government and regional police force. Meeting this requirement will prove particularly difficult for SIF initiatives in Ottawa and Toronto. ${ }^{13}$ The police chiefs from Ottawa and Toronto, Charles Bordeleau and Mark Saunders respectively, ${ }^{3,4}$ and the Mayor of Ottawa Jim Watson have publicly opposed introducing SIFs in their respective cities. ${ }^{4}$ Toronto Mayor John Tory's office has not offered a position on the issue. ${ }^{3}$ Although federal approval can be sought without buy-in from local authorities, SIFs supporters are actively seeking feedback from affected communities and educating people about misconceptions. Consultations with the public and interested stakeholders have started in Ottawa and Toronto led by the Sandy Hill Community Health Centre and the Toronto Board of Health, respectively. ${ }^{14-16}$

\section{ARGUMENTS AGAINST INTRODUCING SIFS}

Those in opposition to introducing SIFs often claim that SIFs simply cannot provide the advertised benefits and would not be able to attract high risk IVDUs to their sites. In 2005, Insite clients were mostly from higher-risk populations: young adults, public injectors, and daily heroin or cocaine users. ${ }^{17}$ These higher-risk populations are often homeless or without stable housing, and often with a high burden of hepatitis $\mathrm{C}$ infection (87.6\% of the surveyed population). ${ }^{18}$ Two years later, Insite remained a site used by higher-risk populations including youth under 30 with $57 \%$ of under 30 IVDUs surveyed reporting to have used Insite..$^{19}$ In 2012, Insite received 376 visits by about 9259 individuals, $27 \%$ of whom were female and $17 \%$ Aboriginal. $^{20}$

Another common argument is that facilitating the injection of illicit substances condones the behaviour leading to increased drug use and a further deterioration in health. This argument is not supported by the evidence. Interviews with Insite clients revealed that the average user has been injecting for 16 years and of the 1065 participants only one reported performing their first injection at the site. ${ }^{21}$ Furthermore, SIFs prevent the serious health problems associated with disease transmission and unsafe injection habits. Using data from surveys at Insite and SIFs in Spain, 69\% of respondents were less likely to share used needles and more likely to practice safer injection practices - sterile water, swabbing sites, correct needle disposal, cooking and filtering drugs, and taking their time..$^{22,23}$ Additionally, Insite clients are often treated by medical staff for injection related infections and remark that it is often easier to seek treatment from Insite than a typical clinic. ${ }^{24}$

Critics also suggest that offering a safe space for IVDUs where they do not have to fear legal recourse makes drug abusers more likely to shoot up and overdose. Studies released in 2008 report that IVDUs at Insite were not more likely to overdose than those who use the facility less often and the prompt medical attention provided at the facility prevented up to 12 fatal overdoses per year over a four-year period. ${ }^{25,26}$ Following Insite's opening, the injection-related mortality rate dropped faster in the areas surrounding Insite compared to Vancouver as a whole. ${ }^{27}$ Some have taken issue with these findings and argue that the study ignored relevant confounding factors, including a drop in heroin supply. ${ }^{28}$

Opponents to SIFs also argue that rehabilitation and detoxification programs should receive more financial support. Over the last twenty years in the Vancouver area, an increased proportion of drug users reported access to methadone maintenance therapy (11.7\% in 1999 to $54.5 \%$ in 2008 ) while a decreased proportion have cited difficulty accessing treatment (19.9\% in 1996 to $3.2 \%$ in 2006). ${ }^{29}$ Insite offers rehabilitation and detoxification services at its facility. In the years following the opening of Insite, $18 \%$ of consistent Insite clients that were surveyed began detoxification therapy and were found to be 1.7 times more likely to enroll in these programs than inconsistent Insite clients. ${ }^{30}$ Insite provides harm reduction in the drug-using population, complementing addiction treatment services and encouraging enrollment.

The most common argument against SIFs is that they will increase the number of drug users in the surrounding area and consequently increase crime rates. Comparing the years before and after Insite's opening (2003 to 2005), there were no significant changes in the rate of drug trafficking, assault or robbery and even a decrease in vehicle break-ins and thefts. ${ }^{31,32}$ Another major concern is the potential increase in used needles littered in parks and public areas. Looking at 6 weeks prior to and 12 weeks following Insite's opening, there was a significant decrease in the number of publicly discarded syringes, injection-related litter and public injections in the surrounding neighbourhoods. ${ }^{33}$ Arguments insinuating that SIFs lead to an increase in public disorder do not appear to hold any merit.

\section{CONCLUSION}

There is a breadth of evidence indicating that Vancouver's safe injection facility, Insite, has demonstrated the ability to control injection-related disease transmission and attract high-risk populations without increasing public disorder or cases of overdose. However, it is understood that what works for Vancouver may not necessarily work in Toronto or Ottawa. The lack of political support will prove to be challenging for municipalities looking to open similar facilities, but given the potential benefits and cost-effectiveness of the Ontario sites, it is worthwhile to pursue these proposals further.

\section{REFERENCES}

1. Vancouver Coastal Health [Internet]. Supervised injection site. [cited $2016 \mathrm{Feb} 25]$. Available from: http://supervisedinjection.vch.ca/

2. Angus Reid Strategies [Internet]. Canadians tend to support Insite, believe in "harm reduction". [cited $2016 \mathrm{Feb} 25]$. Available from: https:// www.angusreidforum.com/MediaServer/3/documents/2008\%20 08\%2020_Insite_ARF.pdf

3. Church E, Stevenson V. Safe injection site proponents push on despite Harper's opposition [Internet]. Globe and Mail, 2015 Aug14. [cited 2016 Feb 04]. Available from: http://www.theglobeandmail.com/news/ 
national/safe-injection-site-proponents-push-on-despite-harpers-opposition/article25967472/

4. Collins, S. Ottawa safe injection site could work- if it overcomes ideology [Internet]. Metro News, 2014 Aug 10. [cited 2016 Feb 04]. Available from: http://www.metronews.ca/views/ottawa/collins-ottawa/2014/08/10/ottawa-safe-injection-site-could-work-if-it-overcomes-ideology

5. Safer Ottawa [Internet]. [cited 2016 Mar 03]. Available from: http:// www.saferottawa.ca

6. Enns EA, Zaric GS, Strike CJ, et al. Potential cost-effectiveness of supervised injection facilities in Toronto and Ottawa, Canada. Addiction. 2016 Mar; 111(3):475-89.

7. Andersen MA, Boyd N. A cost-benefit and cost-effectiveness analysis of Vancouver's supervised injection facility. Int J Drug Policy. 2010 Jan;21(1):70-6.

8. Bayoumi A, Zaric GS. The cost-effectiveness of Vancouver's supervised injection facility. CMAJ. 2008 Nov 18;179(11):1143-51.

9. Wells, P. Harper Swings and Misses on Insite [Internet]. Macleans. 2011 Oct10. [cited 2016 Mar 11]. Available from: http://www.macleans. ca/authors/paul-wells/swing-and-a-miss/

10. No AIDS announcement during 'politicized' week: Ottawa [Internet]. CBC. 2006 Aug17. [cited 2016 Mar 11]. Available from: http://www.cbc. ca/news/canada/no-aids-announcement-during-politicized-week-ottawa-1.573667.

11. Supreme Court Judgement (Canada v PHS Community Services Society). [Internet]. Supreme Court of Canada. 2011 Sept 30. [cited $2016 \mathrm{Feb} 04]$. Available from: scc-csc.lexum.com/scc-csc/scc-csc/en/ item/7960/index.do

12. Mcleod, C. "Access to Information". Canada Parliament. House of Commons [Internet]. Edited Hansard 2015 Mar 13;145(3). 41st Parliament, 2nd session. [cited 2016 Apr 10]. Available from: http:// www.parl.gc.ca/HousePublications/Publication.aspx?Language=E\&Mode $=1 \&$ Parl $=41 \&$ Ses $=2 \&$ DocId $=7882211$

13. Parliament of Canada Bill C-2 [Internet].2015 Jun 18. [cited 2016 Feb 04]. Available from: http://www.parl.gc.ca/HousePublications/Publication .asp $x$ ? Language $=\mathrm{E} \&$ Mode $=1 \&$ Doc $I d=8056955$

14. Jackson, E. Ottawa supervised injection site consultations to start over mayor's objections [Internet]. Metro News. 2016 Apr03. [cited 2016 Apr 10]. Available from: http://www.metronews.ca/news/ottawa/2016/04/03/safe-injection-debate-revived-in-the-capital.html

15. Pfeffer, A. Drug users, neighbours weigh in on safe injection site proposal for Ottawa [Internet]. CBC. 2016 Apr 05. [cited 2016 Apr 10]. Available from: http://www.cbc.ca/news/canada/ottawa/safe-injection-ottawa-consultations-1.3520920

16. Toronto Board of Health pushes ahead with plan for supervised injection sites [Internet]. CBC. 2016 Mar 21. [cited 2016 Apr 10]. Available from: http://www.cbc.ca/news/canada/toronto/supervised-injec$\underline{\text { tion-sites-1.3500978 }}$

17. Wood E, Tyndall MW, Li K, et al. Do supervised injecting facilities attract higher-risk injection drug users? Am J Prev Med. 2005 Aug;29(2):126-30.

18. Wood E, Kerr T, Stoltz J, et al. Prevalence and correlates of hepatitis C infection among users of North America's first medically supervised safer injection facility. Public Health. 2005 Dec;119(12):1111-5.

19. Stoltz JA, Wood E, Miller C, et al. Characteristics of young illicit drug injectors who use North America's first medically supervised safer injection facility. Addiction Research Theory. 2009 Jul;15(1):63-9.

20. Vancouver Coastal Health [Internet]. Supervised Injection Site User Statistics 2012. [cited $2016 \mathrm{Feb} 02$ ]. Available from: supervisedinjec- tion.vch.ca/research/supporting-research/user-statistics

21. Kerr T, Stoltz JA, Tyndall M, et al. Impact of a medically supervised safer injection facility on community drug use pattern: a before and after study. BMJ. 2006 Jan 28;332(7535):220-2.

22. Milloy M-J, Wood E. Emerging role of supervised injecting facilities in human immunodeficiency virus prevention. Addiction. 2009 Apr;104(4):620-1.

23. Stoltz JA, Wood E, Small W, et al. Changes in injecting practices associated with use of a medically supervised safer injection facility. J Pub Health. 2007 Mar;29(1):35-9.

24. Small W, Wood E, Lloyd-Smith E, et al. Accessing care for injection-related infection through a medically supervised injecting facility: a qualitative study. Drug Alcohol Depend. 2008 Nov;98(1-2):159-62.

25. Milloy M-J, Kerr T, Mathias R, et al. Non-fatal overdoses among a cohort of active injection drug users recruited from a supervised injection facility. Am J Drug Alcohol Abuse. 2008;34(4):499-509.

26. Milloy M-J, Kerr T, Tyndall M, et al. Estimated drug overdose death averted by North America's first medically supervised safer injection facility. PLoS ONE. 2008;3(10):e3351.

27. Marshall BDL, Milloy M-J, Wood E, et al. Reduction in overdose mortality after the opening of North America's first medically supervised safer injecting facility: a retrospective population-based study. Lancet. 2011 Apr 23;377(9775):1429-37.

28. Christian G, Pike G, Santamaria J, et al. Overdose death and Vancouver's supervised injection facility. Lancet. 2012 Jan 14;379(9811):117.

29. British Columbia Centre for Excellence in HIV/AIDS [Internet]. Drug situation in Vancouver 2nd edition. June 2013. [cited 2016 Mar 04]. Available from: http://www.cfenet.ubc.ca/sites/default/files/uploads/ news/releases/war_on_drugs_failing_to_limit_drug_use.pdf

30. Wood E, Tyndall MW, Zhang R, et al. Attendance at supervised injecting facilities and use of detoxification services. N Engl J Med. 2006 Jun;354:2512-14.

31. Wood E, Tyndall MW, Lai C, et al. Impact of a medically supervised safer injecting facility on drug dealing and other drug related crimes. Subst Abuse Treat Prev Policy. 2006;1(13).

32. Health Canada [Internet]. Vancouver: Health Canada; c2008. [cited $2016 \mathrm{Feb}$ 04]. Available from: http://www.hc-sc.gc.ca/ahc-asc/pubs/= sites-lieux/insite/index-eng.php

33. Wood E, Kerr T, Small W, et al. Changes in public order after the opening of a medically supervised safer injecting facility for illicit injection drug uses. CMAJ. 2004 Sep 28;171(7):731-4. 